\title{
LATENTNA STRUKTURA PARAMETARA SITUACIONE EFIKASNOSTI KOD HRVATSKIH VRHUNSKIH KOŠARKAŠA SENIORA
}

\author{
Joško Sindik $^{1}$, Igor Jukić ${ }^{2}$ Maja Adžija ${ }^{3}$ \\ ${ }^{1}$ Institut za antropologiju, Zagreb, Hrvatska \\ ${ }^{2}$ Kineziološki fakultet, Sveučilište u Zagrebu, Hrvatska \\ ${ }^{3}$ Ured za međunarodne odnose, Sveučilište u Zagrebu, Hrvatska
}

\section{SAŽETAK}

Cilj istraživanja bio je utvrditi strukturu dimenzija koje se temelje na različitim standardnim parametrima situacione efikasnosti hrvatskih vrhunskih košarkaša. Otkrivanje strukture i odnosa latentnih dimenzija u situacionoj uspješnosti u košarci bi moglo pridonijeti boljem razumijevanju ukupne situacione efikasnosti košarkaša. Analizirano je dvanaest standardnih, te sedam izvedenih parametara situacione efikasnosti u namjernom uzorku košarkaša devet seniorskih timova iz A-1 Hrvatske košarkaške lige u prvenstvu 2006/2007. Analizom glavnih komponenti kod standardnih parametara situacione efikasnosti utvrdili smo postojanje tri glavne komponente, koje sve zajedno tumače preko $76 \%$ ukupne varijanse prostora standardnih parametara situacione efikasnosti. Univarijatne korelacije i analiza glavnih komponenti pokazuju da je i većina standardnih i većina izvedenih parametara situacione efikasnosti međusobno statistički značajno povezana.

Ključne riječi: košarka, komponentna analiza, korelacije, latentne dimenzije.

\section{UVOD}

Košarka je kompleksna polistrukturalna varijabilna aktivnost za koju su karakteristični ciklički i aciklički tipovi kretanja koji prethode osnovnom cilju igre, ubacivanju lopte u koš, kao i sprečavanju protivničkog igrača da osvoji i ubaci loptu u koš. Sama košarkaška igra u svom toku podijeljena je na tri osnovne faze: odbrane, napada i tranzicije (Jukić, 1998), a može se posmatrati i kao određeni niz poslova i zadataka koje svaki igrač obavlja s obzirom na mjesto i ulogu u timu unutar određenog koncepta igre (Trninić, Perica i Dizdar, 1999). Košarka je sport sa kontradiktornim modelom taktike igre s beskonačnim brojem mogućnosti za rješavanje određene situacije u igri, dok je na ekipnom nivou potreban model saradnje - opozicije (Hernandez, 1988). Zato je usklađivanje pojedinačnih i timskih ciljeva, odnosno individualnih i timskih rješenja, izuzetno važno (Gréhaigne, Bouthier i Godbout, 1997; Trninić i saradnici, 1999; Trninić i Dizdar, 2000). Temeljna pretpostavka za uspješno djelovanje pojedinca u smislu obavljanja navedenog niza poslova je skup biranih obilježja antropološkog statusa, povezanih u integralni sklop optimalne sportske pripremljenosti. Obilježja koja determinišu uspjeh u košarci definišu se jednačinom specifikacije, koja određuje optimalni "zbir" karakteristika koje su korelati maksimalnog sportskog postignuća (Milanović, Jukić i Dizdar, 1996). Praćenje i analiza situacione efikasnosti igrača i ekipe u košarkaškoj igri doprinose lakšem praćenju igre od strane gledalaca, a od velike su pomoći trenerima i košarkaškim stručnjacima kao materijal koji omogućuje komparativnu analizu igrača i ekipe u cjelini te imaju svoje mjesto pri planiranju i programiranju trenažnog procesa, ukazuje Maršić (Nakić, 2004). U svrhu praćenja događanja na košarkaškim utakmicama FIBA (Federation International Basketball Association) je standardizovala trinaest pokazatelja situacione efikasnosti koji se prate na svakoj službenoj utakmici. $\mathrm{Na}$ osnovu njih je moguće izračunati različite izvedene parametre. O problemima mjerenja stvarne kvalitete košarkaša sprovedena su brojna naučna istraživanja 
(Dežman, 1996; Dizdar, 2002; Elbel i Allen, 1941; Erčulj, 1995; Swalgin, 1994, 1998). Ovakva istraživanja uglavnom su bila usmjerena na razvijanje ekspertnih sistema za procjenu stvarne kvalitete košarkaša (Swalgin, 1994, 1998; Trninić i saradnici, 1999). Dizdar (2002) je klasifikovao dvije osnovne metode za procjenu ukupne uspješnosti ili stvarne kvalitete košarkaša. Prvu čine postupci za objektivnu procjenu situacione efikasnosti košarkaša, među kojima su: jednostavna linearna kombinacija, jednostavna linearna kombinacija z-vrijednosti, djelomično ponderisane linearne kombinacije, indeks apsolutne i relativne uspješnosti košarkaša, MVP-procjena korisnosti igrača, Swalginovi (1994, 1998) sistem za evaluaciju košarkaša (BES 1 i BES 2), PC sistem za vrednovanje efikasnosti košarkaša. U drugu grupu metoda uvrštavaju se postupci za subjektivnu procjenu situacione efikasnosti košarkaša, koju čine grupe nezavisnih košarkaških eksperata koji određenu grupu košarkaša procjenjuju prema jednom ili više kriterija. Premda je od nabrojanih metoda "PC sustav za vrednovanje efikasnosti košarkaša" dokazano najefikasniji, podjednako efikasna je i metoda djelomično ponderisane linearne kombinacije (Dizdar, 2002), koja koristi koeficijente šuterske efikasnosti umjesto pukih statističkih podataka o broju postignutih poena, te broja neuspješnih šuteva.

U kontekstu ovog istraživanja, dajemo pregled istraživanja autora koji su proučavali standardne pokazatelje situacione efikasnosti košarkaša. Trninić, Perica i Dizdar (2001) dali su spisak kriterijuma za situacijsku evaluaciju efikasnosti elitnih košarkaša u fazi napada i odbrane, utvrdivši sedam kriterija za vrednovanje košarkaša u postavljenoj i tranzicijskoj fazi odbrane, te dvanaest kriterijuma za fazu napada. Milanović, Jukić i Bračić (2001) su utvrdili koliko varijable ubacivanja lopte u koš utiču na rezultate košarkaških utakmica Prvenstva Europe u Barceloni 1997, te su došli do zaključaka da se od sedam varijabli samo tri javljaju kao značajni prediktori konačnog rezultata utakmice, dok je najznačajnija od njih broj uspješnih izvođenja ubacivanja lopte u koš sa linije slobodnih bacanja. Ostale dvije značajne varijable bile su neuspješna ubacivanja za dva i tri poena. Abrams, Barnes i Clement (2008) su nastojali utvrditi odnos između statističkih parametara koje su košarkaši imali prije nastupanja u prvenstvu NBA lige (National Basketball Association) i trajanja sportske karijere u NBA ligi (brojem sezona nastupanja). Uzorak učesnika sadržavao je bekove, krila i centre. Analizirano je jedanaest standardnih parametara situacione efikasnosti, a pokazalo se da postoji značajna mogućnost prognoze trajanja karijere na temelju tih parametara, ali samo za košarkaše na poziciji bekova i krila (ne i za centre).
Kod košarkaša Američkih univerziteta, Swalgin (1994) je uspostavio standarde za procjenu situacione efikasnosti košarkaša prema položaju u igri i vremena za igru. Dizajnirao je računarski program za procjenu efikasnosti košarkaša, u odnosu na poziciju na kojoj igra i njegovu prisutnost u igri. U ostalim sportskim igrama, Janković (1988) je istražio i definisao latentnu strukturu tehničkotaktičkih elemenata u odbojci, na uzorku četiri najbolje odbojkaške ekipe koje su učestvovale u finalnom turniru Kupa bivše Jugoslavije 1981. Na temelju osnovnih tehničko-taktičkih elemenata u odbojci, autor je koristio analizu glavnih komponenti te izdvojio četiri sljedeće latentne dimenzije: cjelokupna igračka efikasnost, efikasnost u podizanju, efikasnost u zadnjem polju te efikasnost igre nakon brzih prekida. Trninić, Viskić-Štalec, Štalec, Dizdar i Birkić (1995) su proveli kvantitativnu analizu igre košarke korišćenjem matematičko-statističkih multivarijatnih postupaka (analiza glavnih komponenti). Analiza je napravljena uzevši u obzir opšte i specifične atribute utakmice i zadatke košarkaša u igri, na osnovu procjena vrhunskih košarkaških stručnjaka (igrača i trenera) te znanja naučnika-praktičara. Faktorska rješenja su pokazala da postoje tri dimenzije košarkaške igre, tri komponente: informaciona, energetska, te socio-motorna interakcija. Korelacija izmedu informacione i socio-motorne interakcijske komponente bila je 0,38, dok je korelacija između energetske i socio-motorne interakcijske komponente bila negativna. Trninić i saradnici (1995) su pokušali odrediti latentnu strukturu košarkaške igre Alpha - faktorskom analizom, na utakmicama Svjetskog prvenstva u košarci u Torontu 1994, te su pronašli četiri relativno nezavisne latentne dimenzije: (1) efikasnost unutrašnjih igrača ili igrača unutar zadnje linije obrane i prednje linije napada; (2) efikasnost vanjskih igrača ili igrača ispred linije obrane i zadnje linije napada; (3) opšta efikasnost napada; (4) efikasnost bacanja lopte u koš iz daljine. Thomson (1994) razlikuje unutrašnje igrače i post-tehniku (okrenutih leđa košu), dok Wissel (1994) opisuje vanjske igrače i specifičnosti tehnike okrenutosti lica prema košu. S druge strane, Javier (1992) dijeli igrače u dvije velike kategorije s obzirom na njihove uloge u igri: vanjske (organizator, realizator i krilo) i unutrašnje (post i pivot) igrače. Eksplorativnom strategijom faktorske analize glavnih komponenata 13 standardnih pokazatelja situacione efikasnosti na uzorku vrhunskih juniorskih košarkaša koji su učestvovali na Juniorskom košarkaškom prvenstvu u Zadru 2000, izolovane su dvije relativno nezavisne latentne dimenzije i imenovane su kao: situaciona tehnička i taktička aktivnost (1) unutrašnjih i (2) vanjskih igrača (Jeličić, Trninić i Jelaska, 2010). Autori zaključuju da niti korišćenje standardnih 
pokazatelja situacione efikasnosti, a niti korišćenje iz njih izvedenih latentnih dimenzija nisu dovoljni za objašnjenje kompleksne strukture košarkaške igre. Cilj istraživanja Šeparovića i Nuhanovića (2008) bio je utvrđivanje latentne strukture u košarci primjenom faktorske analize (alpha metoda, oblimin kriterijum transformacije) na 15 standardnih pokazatelja situacione uspješnosti (FIBA), na uzorku od 30 utakmica u Bosanskohercegovačkoj Ligi 6 koja se igrala za prvaka države. Analizirajući strukturu situacionih pokazatelja koji utiču na uspješnost najjačih košarkaških klubova u Bosni i Hercegovini u borbi za titulu šampiona države u košarci, pokazalo se da postoje četiri latentne dimenzije, koje su imenovane: uspješnost šuta sa bliske udaljenosti, uspješnost šuta sa srednje udaljenosti, generalna odbrambena uspješnost igrača i specifična odbrambena pokretljivost. Međutim, autori smatraju da je za kompletnu analizu latentne strukture neophodno proširiti bazu situacionih pokazatelja.

Cilj ovog istraživanja bio je utvrditi strukturu dimenzija koja su u osnovi različitih standardnih parametara situacione efikasnosti kod hrvatskih vrhunskih seniorskih košarkaša. Naime, otkrivanje strukture i relacija latentnih dimenzija u osnovi ove situacione efikasnosti u košarci moglo bi doprinijeti lakšem razumijevanju ukupne situacione efikasnosti vrhunskih hrvatskih seniorskih košarkaša. S druge strane, ono bi moglo doprinijeti i kvalitetnijem radu trenera, koji bi više sistemski mogao organizovati trenažni proces, u smislu diferenciranog djelovanja na bitne latentne dimenzije u osnovi ukupne situacione efikasnost košarkaša.

\section{METODE}

\section{Učesnici}

Populacija iz koje je namjerni uzorak učesnika izvučen bili su vrhunski seniorski košarkaši, koji su igrali u devet muških seniorskih timova A-1 Hrvatske muške košarkaške lige iz prvenstva 2006/2007. godine: "Cedevita", "Svjetlost", "Borik", "Kvarner", "Dubrava", "Dubrovnik", "Alkar", "Šibenik" te "Osijek". Finalni uzorak učesnika (74 košarkaša) je selekcionisan iz inicijalnog uzorka od 107 učesnika. Uslov za izbor igrača u finalni uzorak učesnika bio je broj minuta provedenih u igri (minimalno deset minuta provedenih u igri po utakmici), odnosno broj odigranih utakmica (minimalno osam utakmica u kojima je pojedinac nastupio). Igrači ekipa su ispitani uz dopuštenje Hrvatskog košarkaškog saveza, klubova i samih igrača, unutar perioda odigravanja šestog do osmog kola prvenstva A-1 lige (od decembra 2006. do polovine januara 2007.).

\section{Varijable}

Kriterijumi za kvantitativnu evaluaciju igrača preuzeti su iz prethodno referisanih radova kod nas (Dizdar, 2002). U ovom se radu koristila metoda djelomično ponderisane linearne kombinacije za procjenu ukupne kvalitete košarkaša (Ibid). Trinaest je standardnih parametara situacione efikasnosti, koji uključuju podatke o uspješnosti šuteva, skokove, osvojene i izgubljene lopte, asistencije, blokade, lične greške. Na osnovu standardnih parametara situacione efikasnosti, deducirano je i sedam izvedenih koeficijenata situacione efikasnosti košarkaša: iskorišćenost šuta za dva poena, iskorišćenost šuta za tri poena, iskorišćenost slobodnih bacanja, efikasnost šuta za dva poena, efikasnost šuta za tri poena, efikasnost slobodnih bacanja te ukupne situacione efikasnosti (Ibid). Podatak o broju blokada šuta je u ovom istraživanju izostavljen, kao rijedak događaj o čijoj zastupljenosti nismo imali podatke. Izvedeni parametri situacione efikasnosti: Koeficijent iskorišćcnosti šuta za dva poena - XK2IS = XP2 / (XP2 + XN2); Koeficijent iskorišćenosti šuta za tri poena $-\mathrm{XK} 3 \mathrm{IS}=\mathrm{XP3} /(\mathrm{XP} 3+\mathrm{XN} 3)$; Koeficijent iskorišćenosti slobodnih bacanja - XK1IS = XP1 / (XP1 + XN1); Koeficijent efikasnosti šuta za dva poena $-\mathrm{XK2UC}=2 \times \mathrm{XP} 2 \times \mathrm{XK2IS}$; Koeficijent efikasnosti šuta za tri poena - XK3UC $=3 \times$ XP3 $x$ XK3IS; Koeficijent efikasnosti slobodnih bacanja $\mathrm{XK1UC}=\mathrm{XP1} \times \mathrm{XK1IS}$; Ukupna situaciona efikasnost $-\mathrm{XDLK}=\mathrm{XP} 1+2 \times \mathrm{XP} 2+3 \times \mathrm{XP} 3+\mathrm{XSO}+\mathrm{XSN}$ $+\mathrm{XA}+\mathrm{XOL}-0,5 \mathrm{XN} 1-\mathrm{XN} 2-\mathrm{XN} 3-\mathrm{XIL}-\mathrm{XOP}$. Analizirane su sve utakmice prvenstva (koristeći službenu statistiku Hrvatskog košarkaškog saveza s portala www.kosarka.hr), tj. po šesnaest utakmica za svaki od devet timova, u "dvokružnom" sistemu takmičenja.

\section{Metode obrade podataka}

Da bi se utvrdila struktura dimenzija koja su u osnovi skupa standardnih parametara situacione efikasnosti u košarci, sproveden je postupak komponentne analize, gdje je broj značajnih glavnih komponenti određen Guttman-Kaiserovim kriterijumom. Kao metoda ekstrakcije primijenjena je metoda glavnih komponenti s Varimax rotacijom. Za detaljnu analizu međusobnih odnosa pojedinačnih varijabli unutar skupa promjenljivih, utvrđene su i interkorelacije (Pearson) između svih varijabli skupa parametara situacione efikasnosti učinkovitosti košarkaša. 


\section{REZULTATI}

U Tabeli 1 je data deskriptivna statistika standardnih i izvedenih parametara situacione efikasnosti kod košarkaša seniorske A-1 Hrvatske košarkaške lige.

U Tabeli 2 je uočljivo da je pronađeno čak 48 (od teoretski mogućih 72) statistički značajnih korelacija, većinom srednje veličine. Visoko i značajno koreliraju međusobno komplementarne varijable: broj uspješnih i neuspješnih šuteva za dva poena, broj uspješnih i neuspješnih šuteva za tri poena, broj uspješnih i neuspješnih slobodnih bacanja. Najmanji broj značajnih korelacija s ostalima pronađen je kod broja uspješnih i neuspješnih šuteva za tri poena. Izuzev visokih i značajnih korelacija između međusobno komplementarnih varijabli, dakle uspješnih i neuspješnih šuteva za dva, tri i jedan poen, za svaki standardni parametar pronađeno je po 9 ili 10 značajnih korelacija s ostalima. Stoga je realno zaključiti da standardni pokazatelji situacione efikasnosti pokazuju u prosjeku relativno visoku međusobnu povezanost.

U Tablei 3 dat je prikaz interkorelacijske matrice za grupu varijabli izvedenih parametara situacione efikasnosti za uzorak košarkaša seniorskih momčadi A-1 Hrvatske muške košarkaške lige. Ukupno je pronađeno 10 (od teoretski mogućih 28) statistički značajnih pozitivnih korelacija koje po vrijednostima variraju od niskih do vrlo visokih. Najveći broj statistički značajnih korelacija (4) pronađen je između ukupne situacione efikasnosti (XDLK) i: iskorišćenosti šuta za dva poena, efikasnosti šuta za dva poena; efikasnosti šuta za tri poena, XK1UC dakle efikasnosti šuta za jedan poen. Takođe, četiri značajne pozitivne korelacije pronađene su između efikasnosti šuta za tri poena, i: ukupne situacione efikasnosti, efikasnosti šuta za jedan poen, iskorišćenosti šuta za tri poena te iskorišćenosti šuta za jedan poen. Tri su značajne korelacije pronađene za XK1UC, dakle efikasnost šuta za jedan poen, i: efikasnost šuta za dva poena, ukupna situaciona efikasnost, te efikasnost šuta za tri poena. Takođe, tri su značajne korelacije pronađene i između XK2UC, dakle efikasnost šuta za dva poena, i: iskorišćenost šuta za dva poena, efikasnost šuta za jedan poen i ukupne situaciona efikasnost. Značajne pozitivne korelacije pronađene su između izvedenih parametara koji se odnose na šut za dva poena, tj. koeficijenta efikasnosti šuta za dva poena) i koeficijenta iskorišćenosti šuta za dva poena. Značajna povezanost pronađena je i između koeficijenta efikasnosti šuta za tri poena i koeficijenta iskorišćenosti šuta za tri poena. Između koeficijenta efikasnosti slobodnih bacanja i koeficijenta iskoriščenosti slobodnih bacanja, korelacija nije statistički značajna.
U Tabeli 4 je vidljivo da je metodom analize glavnih komponenata utvrđeno postojanje tri latentne dimenzije, koje zajedno objašnjavaju preko $76 \%$ varijance varijabli standardnih parametara sitaucione efikasnosti (čiji su karakteristični korijeni statistički značajni prema Kaiser-Guttmanovom kriterijumu, tj. veći od 1). Nakon varimax rotacije, prva ekstrahirana komponenta objašnjava skoro $29 \%$ objašnjene varijance, a u najvećim je korelacijama s varijablama skokovi u fazi odbrane i skokovi u fazi napada (XSO i XSN), te uspješni i neuspješni šutevi za dva poena (XP2 i XN2).

Riječ je o najfrekventnijim standardnim parametrima situacione efikasnosti, koji u košarci najčešće donose i "prevagu" za krajnji rezultatski ishod utakmice. Druga ekstrahovana komponenta objašnjava 17\% ukupne varijance, a u najvećim je korelacijama sa varijablama sa uspješnim i neuspješnim šutevima za tri poena (XP3 i XN3). Dakle, riječ je o relativno rijetkom, ali često za ishod meča presudnom događaju na košarkaškoj utakmici (šut za tri poena). Treća ekstrahovana komponenta objašnjava 30\% varijance, a u najvećim je korelacijama sa varijablama preostalih standardnih parametara situacione efikasnosti košarkaša (izuzev parametara koji su u visokim korelacijama s prvim i drugim faktorom). Može se okvirno reći da su to u principu "srednje česti" događaji na košarkaškoj utakmici. Najveće vrijednosti komunaliteta dobijene su za varijable: broj uspješnih šuteva za dva poena, tj. XP2, te broj izgubljenih lopti, tj. XIL $(0,83)$. Njima se može objasniti najveći dio varijance. Vjerojatno je da su najveće vrijednosti komunaliteta dobijene za relativno česte događaje na košarkaškoj utakmici, koje su podjednako zastupljeni za igrače na svim pozicijama u timu. Najmanje vrijednosti komunaliteta dobijene su za varijable: broj neuspješnih slobodnih bacanja, tj. XN1, broj osvojenih lopti, tj. XOP $(0,64)$, te broj asistencija, tj. XA $(0,66)$, koje su najvjerojatnije karakteristične samo za pojedine pozicije igrača, tj. bekove i "playmakere".

\section{DISKUSIJA}

Rezultati komponentne analize pokazuju kako se u prostoru standardnih parametara situacione efikasnosti izdvajaju tri faktora. Prvi faktor najviše saturiraju na košarkaškoj utakmici najfrekventniji standardni parametri situacione efikasnosti, koji u košarci najčešće donose i "prevagu" za krajnji rezultatski ishod utakmice (skokovi u fazi napada te odbrane i uspješni i neuspješni šutevi za dva poena). Drugi faktor u prostoru standardnih parametara opisuje relativno rijetke, ali često za ishod meča presudne događaje na košarkaškoj utakmici (uspješni i neuspješni šut za tri poena). Treći faktor u 
prostoru standardnih parametara opisuje "srednje česte" događaje na košarkaškoj utakmici: asistencije, šuteve slobodnih bacanja, osvojene i izgubljene lopte, lične greške. I relativni doprinos ovih faktora tumači važnost pojedinih parametara situacione efikasnosti za tumačenje cijelog prostora situacione efikasnosti košarkaša. Najčešći (prvi faktor) i srednje česti (treći faktor) u prostoru parametara situacione efikasnosti zajedno tumače skoro $60 \%$ ukupnog varijabiliteta. Šutevi za tri poena izdvajaju se kao izolovani entitet, koji u relativnom odnosu (definisan je pomoću samo dvije varijable) daje značajan doprinos tumačenju prostora situacione efikasnosti. Postoji određena sličnost rezultatima koje su dobili Trninić i saradnici (1995), budući da dimenzija efikasnosti unutrašnjih igrača ili igrača unutar zadnje linije odbrane i prednje linije napada odgovara donekle prvom faktoru iz našeg istraživanja, dok naš drugi faktor podsjeća na dimenziju efikasnosti bacanja lopte u koš iz daljine. Sličnost postoji i s latentnim dimenzijama koje su dobili Jeličić i saradnici (2010): prvi faktor odgovara prvenstveno situacionoj tehničkoj i taktičkoj aktivnosti unutrašnjih, a drugi i treći faktor aktivnosti vanjskih igrača. Sa istraživanjem Šeparovića i Nuhanovića (2008), latentna

\section{TABELA 1}

Deskriptivna statistika parametara situacijske učinkovitosti kod košarkaša seniorske A-1 Hrvatske košarkaške lige.

\begin{tabular}{lrrrrrrrrrr}
\hline Varijable & $M$ & Min & \multicolumn{1}{c}{ Max } & \multicolumn{1}{c}{$R$} & \multicolumn{1}{c}{ Var } & $S D$ & Skew & Kurt & Max D & $p$ \\
\hline XP2 & 34,03 & 2,00 & 115,00 & 113,00 & 515,53 & 22,71 & 1,07 & 1,14 & 0,12 & 0,20 \\
\hline XN2 & 26,99 & 4,00 & 79,00 & 75,00 & 246,81 & 15,71 & 0,93 & 0,92 & 0,08 & 0,20 \\
\hline XP3 & 12,00 & 0,00 & 39,00 & 39,00 & 85,18 & 9,23 & 0,74 & 0,07 & 0,11 & 0,20 \\
\hline XN3 & 23,12 & 0,00 & 61,00 & 61,00 & 272,90 & 16,52 & 0,51 & $-0,56$ & 0,12 & 0,20 \\
\hline XP1 & 24,12 & 1,00 & 72,00 & 71,00 & 262,16 & 16,19 & 0,94 & 0,51 & 0,14 & 0,15 \\
\hline XN1 & 10,22 & 0,00 & 97,00 & 97,00 & 153,35 & 12,38 & 4,90 & 33,01 & 0,21 & 0,01 \\
\hline XA & 22,51 & 1,00 & 105,00 & 104,00 & 371,18 & 19,27 & 2,23 & 6,13 & 0,18 & 0,05 \\
\hline XSN & 13,88 & 1,00 & 48,00 & 47,00 & 114,11 & 10,68 & 1,28 & 1,32 & 0,17 & 0,05 \\
\hline XSO & 31,20 & 2,00 & 87,00 & 85,00 & 376,22 & 19,40 & 0,84 & 0,35 & 0,09 & 0,05 \\
\hline XOL & 14,45 & 0,00 & 34,00 & 34,00 & 60,41 & 7,77 & 0,24 & $-0,60$ & 0,07 & 0,20 \\
\hline XOP & 33,23 & 4,00 & 64,00 & 60,00 & 146,40 & 12,10 & 0,08 & $-0,49$ & 0,09 & 0,20 \\
\hline XIL & 21,39 & 3,00 & 55,00 & 52,00 & 134,41 & 11,59 & $-0,69$ & $-0,31$ & 0,13 & 0,20 \\
\hline XK2IS & 0,54 & 0,17 & 0,72 & 0,55 & 0,01 & 0,10 & $-0,72$ & 1,05 & 0,08 & 0,15 \\
\hline XK3IS & 0,31 & 0,00 & 0,70 & 0,70 & 0,02 & 0,15 & $-0,39$ & 0,68 & 0,16 & 0,20 \\
\hline XK1IS & 0,73 & 0,40 & 1,00 & 0,60 & 0,02 & 0,13 & $-0,12$ & $-0,29$ & 0,07 & 0,10 \\
\hline XK2UC & 38,88 & 0,67 & 147,77 & 147,10 & 855,97 & 29,26 & 0,74 & 0,14 & 0,14 & 0,20 \\
\hline XK3UC & 8,84 & 0,00 & 34,97 & 34,97 & 58,89 & 7,67 & 0,51 & $-0,44$ & 0,13 & 0,15 \\
\hline XK1UC & 17,52 & 0,50 & 55,74 & 55,24 & 146,79 & 12,12 & 1,99 & 7,35 & 0,14 & 0,20 \\
\hline XDLK & 100,51 & $-1,41$ & 287,68 & 289,09 & 4217,37 & 64,94 & 0,72 & 0,34 & 0,08 & 0,20 \\
\hline
\end{tabular}

Legenda: M - Aritmetička sredina; Min - Minimum; Max - Maksimum; R - Rang; Var - Varijansa; SD - Standardna devijacija; Skew - Skjunis; Kurt - Kurtozis; p - Vjerovatnoća; XP2 - Broj uspješnih šuteva za dva poena; XN2 - Broj neuspješnih šuteva za dva poena; XP3 - Broj uspješnih šuteva za tri poena; XN3 - Broj neuspješnih šuteva za tri poena; XP1 - Broj uspješnih slobodnih bacanja; XN1 - Broj neuspješnih slobodnih bacanja; XA - Broj asistencija; XSN - Broj skokova u napadu; XSO - Broj skokova u odbrani; XOL - Broj osvojenih lopti; XOP - Broj ličnih grešaka; XIL - Broj izgubljenih lopti; XK2IS - Koeficijent iskorištenosti šuta za dva poena; XK3IS - Koeficijent iskorištenosti šuta za tri poena; XK1IS - Koeficijent iskorištenost slobodnih bacanja; XK2UC - Koeficijent efikasnosti šuta za dva poena; XK3UC - Koeficijent efikasnosti šuta za tri poena; XK1UC - Koeficijent efikasnosti slobodnih bacanja; XDLK - Ukupna situaciona efikasnost. 
TABELA 2

Interkorelacije standardnih parametara situacione efikasnosti

kod košarkaša seniorske A-1 Hrvatske košarkaške lige.

\begin{tabular}{l|cccccccccccc}
\hline Varijable & XP2 & XN2 & XP3 & XN3 & XP1 & XN1 & XA & XSN & XSO & XOL & XOP & XIL \\
\hline XP2 & 1,000 & & & & & & & & & & & \\
\hline XN2 & $\mathbf{0 , 8 2 5}$ & 1,000 & & & & & & & & & & \\
\hline XP3 & 0,004 & 0,066 & 1,000 & & & & & & & & & \\
\hline XN3 & 0,041 & 0,134 & $\mathbf{0 , 8 3 8}$ & 1,000 & & & & & & & & \\
\hline XP1 & $\mathbf{0 , 6 4 5}$ & $\mathbf{0 , 6 3 5}$ & $\mathbf{0 , 2 9 2}$ & $\mathbf{0 , 3 2 8}$ & 1,000 & & & & & & & \\
\hline XN1 & $\mathbf{0 , 5 0 4}$ & $\mathbf{0 , 4 7 7}$ & $-0,118$ & 0,081 & $\mathbf{0 , 6 1 8}$ & 1,000 & & & & & & \\
\hline XA & $\mathbf{0 , 2 6 9}$ & $\mathbf{0 , 3 2 2}$ & 0,206 & 0,165 & $\mathbf{0 , 3 9 9}$ & $\mathbf{0 , 2 8 8}$ & 1,000 & & & & & \\
\hline XSN & $\mathbf{0 , 7 1 7}$ & $\mathbf{0 , 5 4 3}$ & $-0,133$ & $-0,089$ & $\mathbf{0 , 4 2 1}$ & $\mathbf{0 , 2 6 8}$ & $-0,037$ & 1,000 & & & & \\
\hline XSO & $\mathbf{0 , 7 1 4}$ & $\mathbf{0 , 6 0 7}$ & 0,030 & 0,127 & $\mathbf{0 , 4 8 5}$ & $\mathbf{0 , 3 8 1}$ & 0,117 & $\mathbf{0 , 7 5 9}$ & 1,000 & & & \\
\hline XOL & $\mathbf{0 , 4 8 8}$ & $\mathbf{0 , 5 6 8}$ & $\mathbf{0 , 3 7 8}$ & $\mathbf{0 , 3 6 9}$ & $\mathbf{0 , 5 9 2}$ & $\mathbf{0 , 3 8 6}$ & $\mathbf{0 , 5 6 2}$ & 0,201 & $\mathbf{0 , 4 1 5}$ & 1,000 & & \\
\hline XOP & $\mathbf{0 , 4 5 7}$ & $\mathbf{0 , 5 4 6}$ & 0,147 & 0,212 & $\mathbf{0 , 5 9 1}$ & $\mathbf{0 , 3 6 8}$ & $\mathbf{0 , 4 6 4}$ & $\mathbf{0 , 4 2 9}$ & $\mathbf{0 , 4 7 7}$ & $\mathbf{0 , 6 5 6}$ & 1,000 & \\
\hline XIL & $\mathbf{0 , 6 7 7}$ & $\mathbf{0 , 6 7 8}$ & 0,193 & $\mathbf{0 , 3 0 0}$ & $\mathbf{0 , 7 3 5}$ & $\mathbf{0 , 5 3 3}$ & $\mathbf{0 , 6 7 9}$ & $\mathbf{0 , 3 6 3}$ & $\mathbf{0 , 4 7 6}$ & $\mathbf{0 , 6 3 7}$ & $\mathbf{0 , 6 3 0}$ & 1,000 \\
\hline
\end{tabular}

Legenda: XP2 - Broj uspješnih šuteva za dva poena; XN2 - Broj neuspješnih šuteva za dva poena; XP3 - Broj uspješnih šuteva za tri poena; XN3 - Broj neuspješnih šuteva za tri poena; XP1 - Broj uspješnih slobodnih bacanja; XN1 - Broj neuspješnih slobodnih bacanja; XA - Broj asistencija; XSN - Broj skokova u napadu; XSO - Broj skokova u odbrani; XOL - Broj osvojenih lopti; XOP - Broj ličnih grešaka; XIL - Broj izgubljenih lopti.

TABELA 3

Interkorelacije iqvedenih parametara situacijske uönkovitosti

kod košarkaša seniorske A-1 Hrvatske muške košarkaške lige.

\begin{tabular}{l|rrrrrrr}
\hline \multicolumn{1}{c|}{ Varijable } & XK2IS & XK3IS & XK1IS & XK2US & XK3US & XK1US & XDLK \\
\hline XK2IS & 1,000 & & & & & & \\
\hline XK3IS & 0,055 & 1,000 & & & & & \\
\hline XK1IS & $-0,113$ & 0,244 & 1,000 & & & & \\
\hline XK2UC & $\mathbf{0 , 5 6 8}$ & $-0,047$ & $-0,169$ & 1,000 & & & \\
\hline XK3UC & 0,065 & $\mathbf{0 , 6 1 3}$ & $\mathbf{0 , 3 4 9}$ & $-0,022$ & 1,000 & & \\
\hline XK1UC & 0,172 & 0,187 & 0,170 & $\mathbf{0 , 5 3 0}$ & $\mathbf{0 , 3 7 0}$ & 1,000 & \\
\hline XDLK & $\mathbf{0 , 4 8 4}$ & 0,196 & $-0,017$ & $\mathbf{0 , 8 7 1}$ & $\mathbf{0 , 3 4 0}$ & $\mathbf{0 , 6 8 3}$ & 1,000 \\
\hline
\end{tabular}

Legenda: XK2IS - Koeficijent iskorišćenosti šuta za dva poena; XK3IS - UKoeficijent iskorišćenosti šuta za tri poena; XK1IS - Koeficijent iskorišćenosti slobodnih bacanja; XK2UC - Koeficijent efikasnosti šuta za dva poena; XK3UC - Koeficijent efikasnosti šuta za tri poena; XK1UC - Koeficijent efikasnosti slobodnih bacanja; XDLK - Ukupna situaciona efikasnost.

struktura dobijena u našem istraživanju pokazuje određenu podudarnost između efikasnosti šuta s bliske udaljenosti i našeg prvog faktora, efikasnosti šuta sa srednje udaljenosti i drugog faktora, generalne odbrambene efikasnosti igrača i specifične odbrambene pokretljivosti i našeg trećeg faktora. I na nivou analize pojedinačnih povezanosti između varijabli, standardni parametri situacione efikasnosti i u ovom istraživanju pokazuju u prosjeku relativno visoku međusobnu pozitivnu povezanost. I na ovaj način može se pokazati da standardni parametri situacione efikasnosti koherentno opisuju "opštu" situacionu efikasnost košarkaša u nizu 


\section{TABELA 4}

naliza glavnih komponenti s varimax rotacijom (standardni parametri

situacione efikasnosti košarkaša seniorske A-1 Hrvatske muške košarkaške lige).

\begin{tabular}{lrrrr}
\hline \multirow{2}{*}{ Varijable } & \multicolumn{3}{c}{ Faktori } & \multirow{2}{*}{$R^{2}$} \\
\cline { 2 - 4 } & \multicolumn{1}{c}{1} & \multicolumn{1}{c}{3} & \multicolumn{1}{c}{3} \\
\hline XP2 & $\mathbf{0 , 8 1 0}$ & $-0,034$ & 0,431 & 0,840 \\
\hline XN2 & $\mathbf{0 , 6 7 9}$ & 0,045 & 0,526 & 0,737 \\
\hline XP3 & $-0,057$ & $\mathbf{0 , 9 5 5}$ & 0,101 & 0,820 \\
\hline XN3 & 0,027 & $\mathbf{0 , 9 2 7}$ & 0,146 & 0,797 \\
\hline XP1 & 0,497 & 0,253 & $\mathbf{0 , 6 4 0}$ & 0,744 \\
\hline XN1 & 0,346 & $-0,161$ & $\mathbf{0 , 5 8 7}$ & 0,594 \\
\hline XA & $-0,155$ & 0,077 & $\mathbf{0 , 8 6 9}$ & 0,657 \\
\hline XSN & $\mathbf{0 , 9 1 5}$ & $-0,105$ & 0,021 & 0,747 \\
\hline XSO & $\mathbf{0 , 8 6 6}$ & 0,084 & 0,180 & 0,687 \\
\hline XOL & 0,256 & 0,355 & $\mathbf{0 , 7 2 0}$ & 0,669 \\
\hline XOP & 0,407 & 0,165 & $\mathbf{0 , 6 1 9}$ & 0,637 \\
\hline XIL & 0,379 & 0,149 & $\mathbf{0 , 8 2 0}$ & 0,827 \\
\hline CR & 3,473 & 2,064 & 3,611 & \\
\cline { 1 - 3 }$\%$ EV & 28,940 & 17,198 & 30,088 & \\
\hline
\end{tabular}

Legenda: XP2 - Broj uspješnih šuteva za dva poena; XN2 - Broj neuspješnih šuteva za dva poena; XP3 - Broj uspješnih šuteva za tri poena; XN3 - Broj neuspješnih šuteva za tri poena; XP1 - Broj uspješnih slobodnih bacanja; XN1 - Broj neuspješnih slobodnih bacanja; XA - Broj asistencija; XSN - Broj skokova u napadu; XSO - Broj skokova u obrani; XOL - Broj osvojenih lopti; XOP - Broj ličnih grešaka; XIL - Broj izgubljenih lopti; $\mathbf{R}^{2}$ - Kvadrat multiple korelacije; CR - Karakteristični korijenovi; $\%$ EV - \% objašnjene varijanse.

košarkaških utakmica. Dakle, izvedeni parametar ukupne sitaucione efikasnosti su praktično opravdana mjera prostora situacione efikasnosti košarkaša. Međusobno komplementarne varijable pokazale su najveću povezanost, što znači da košarkaši koji najviše uspješno šutiraju za dva, tri poena ili za jedan poen, češće i neuspješno šutiraju. To može biti još jedan pokazatelj opravdanosti tumačenja da se košarkaši razlikuju ne samo po ukupnom vremenu koje provode u igri (kao član prve petorke ili kao rezrevni igrači), već i u odnosu na poziciju odnosno ulogu u timu, koja im određuje i oblike (parametre) situacione efikasnosti (bek, krilo, centar, krilni centar). Najmanji broj značajnih korelacija s ostalim varijablama parametara situacione efikasnosti pronađen je kod uspješnih i neuspješnih šuteva za tri poena, što dodatno potvrđuje rezultate faktorske analize, dakle izdvojenog faktora koji opisuje šut za tri poena. Vjerojatno je da su šutevi za tri poena tehnički element koji zavisi od specifičnog treningu, pa se stoga i selektivno koristi u situacijama košarkaške utakmice. S druge strane, oni su i relativno rijetki na košarkaškim utakmicama. Komentarisanje interkorelacije izvedenih parametara situacione efikasnosti samo je djelomično opravdano, zbog većeg broja spurioznih korelacija uslovljenih istim standardnim parametrima situacione efikasnosti u formulama za izračunavanje izvedenih parametara. Povezanost između izvedenim parametrima efikasnosti je vjerojatno logična posljedica različite logike koncepata izvedenih parametara, koji sadrže praktički tri različite vrste koeficijenata: efikasnost šuteva, iskorišćenost šuteva, te ukupnu sitauciona efikasnost. Koeficijenti efikasnosti šuteva za dva, tri i jedan poen međusobno su značajnije povezani nego koeficijenti iskorišćenosti šuteva. Takođe, koeficijenti efikasnosti šuteva bolje su povezani s ukupnom situacionom efikasnošću košarkaša. Jedan razlog za to je svakako činjenica da su korelacije između ukupne situacione efikasnosti i koeficijenata efikasnosti šuteva spuriozne, jer su posljedica logike definisanja formule izračunavanja navedenih koeficijenata. Ukupna situaciona efikasnost izvodi se iz koeficijenata efikasnosti šuta, a ne iz koeficijenata iskorišćenosti šuta. Koeficijenti efikasnosti šuta (kao i ukupna situaciona efikasnost) uključuju ne samo procenat uspješnih šuteva (dakle 
odnos broja uspješnih šuteva u odnosu na ukupni broj šuteva), već i broj uspješnih pokušaja šuta. Međutim, bolja međusobna povezanost koeficijenata efikasnosti u odnosu na koeficijente iskorišćenosti može indicirati i veću vjerovatnoću da koeficijenti efikasnosti bolje opisuju ono što je nazvano "bolja kvaliteta" (ukupna situaciona efikasnost) košarkaša. Naime, situaciona efikasnost ili "kvalitetan" košarkaš je onaj koji je ne samo optimalno efikasan u relativno uskom domenu zaduženja koja su mu "propisani" instrukcijama koje mu je dao trener ili pozicijom koju igra u timu. Kvalitetan košarkaš je spreman preuzeti odgovornost za tim u cjelini, npr. u smislu šutiranja na koš u situaciji kad je suigrač koji je primarno zadužen za to dobro čuvan od protivnika. Stoga je vjerojatnije da upravo koeficijenti efikasnosti bolje odražavaju realnu (a ne samo matematičku) ukupnu situacionu efikasnost košarkaša, koji je, bez obzira na poziciju u timu, "dovoljno dobar" u svim vrstama šuteva, a za njih se odlučuje češće nego prosječno efikasni košarkaš u timu (Sindik, 2009).

Glavna prednost istraživanja bila je u činjenici da su ispitani praktično svi dostupni košarkaši u istraživanom prvenstvu A-2 košarkaške lige. Odatle, pronađene zakonitosti mogu vrijediti upravo za konkretni uzorak (praktično populaciju) košarkaša, što može biti podsticaj za kvalitetniji rad trenera. Međutim, na manju mogućnost generalizacije rezultata mogu utjecati razlozi: mali i višestruko selekcionisani uzorak učesnika, specifičnost hrvatske populacije vrhunskih seniorskih košarkaša, specifičnost konkretnog takmičenja (u istraživanom prvenstvu niti jedna ekipa nije mogla ispasti iz lige, što je moglo utjecati na manje zalaganje ekipe koje su se borile za opstanak u A-1 ligi). U budućim bi se istraživanjima moglo pokušati donekle povećati broj učesnika (u smislu pokušaja ispitivanja povrijeđenih i iz drugih razloga odsutnih igrača), što je moguće postići samo u minimalnoj mjeri. Pojam "vrhunskih košarkaša" u odnosu na nabrojane specifičnosti uistinu značajno varira od države do države, zavisno o takmičarskom kvaliteti takmičenja u konkretnoj državi (koja često zavisi o finansijskim mogućnostima klubova da zadrže vlastite perspektivne igrače). Na kvalitet košarkaških takmičenja u našoj zemlji se u principu ne može bitno utjecati, izuzev dugoročno, promjenom sistema takmičenja te finansijskih mogućnosti klubova. Zato je jedno od rješenja za buduća istraživanja i višestruka replikacija istovrsnog istraživanja tokom većeg broja košarkaških prvenstava, gdje bi se te male razlike u pojmu hrvatskog "vrhunskog košarkaša" možda mogle reflektirati. Za dugoročno povećanje takmičarske neizvjesnosti (tj. izjednačenosti ekipa koje se takmiče u prvenstvu), možda bi se moglo posegnuti za rješenjima sličnim onom u američkoj NBA-ligi. Svojevrsna "draft"-lista, gdje bi rezultatski neuspješnije ekipe iz prethodnog prvenstva mogle imati prednost pri izboru kvalitetnih mladih igrača, moglo bi ujednačiti takmičarsku kvalitetu pojedinih timova. $\mathrm{Na}$ nivou praktičnih implikacija, na osnovu podataka o latentnoj strukturi bilo bi moguće košarkaški situacioni trening podijeliti u tri dijela: (1) situaciono uvježbavanja skokova kombinovanih sa šutevima za dva poena; (2) situaciono uvježbavanja šuteova za tri poena; (3) situacionog uvježbavanja ostalih parametara situacione efikasnosti - asistencija, šuteva slobodnih bacanja, osvojenih lopti, a smanjenja broja izgubljenih lopti te ličnih grešaka.

\section{ZAKLJUČCI}

Distribucija parametara situacione efikasnosti u prosjeku slijedi "uobičajenu" distribuciju događaja na nivou košarkaške utakmice te košarkaškog takmičenja u cjelini, koji su međusobno u velikoj mjeri statistički značajno povezani. Pronađene su tri osnovne latentne dimenzije koje tumače prostor situacione efikasnosti košarkaša, koje se međusobno mogu razlikovati po velikoj zastupljenosti događaja na košarkaškoj utakmici.

\section{LITERATURA}

Abrams, W., Barnes, J. C., \& Clement, A. (2008). Relationship of selected pre-NBA career variables to NBA players' career longevity. The sport journal, 11(2). Retrived from http://www. thesportjournal.org/article/relationshipselected-pre-nba-career-variables-nba-playerscareer-longevity.

Dežman, B. (1996). Dijagnosticiranje morfološkoga, motoričkoga i igračkoga statusa mladih košarkaša [Diagnosing morphological, motor and the playing status of the youth basketball players]. Kineziologija, 28(2), 42-45.

Dizdar, D. (2002). V rednovanje skupa metoda za procjenu stvarne kvalitete košarkaša [Evaluation expensive method to assess the actual quality of basketball]. Unpublished doctoral dissertation, University of Zagreb, Faculty of Kinesiology.

Elbel, E. R., \& Allen, F. (1941). Evaluating team and individual performance in basketball. Research quaterly, 12(3), 538-557.

Erčulj, F. (1997). Usporedba različitih kriterija učinkovitosti u košarci [Comparison of different efficiency criteria in Basketball]. Kineziologija, 29(1), 42-48. 
Gréhaigne, J.-F., Bouthier, D., \& Godbout, P. (1997). Performance Assessment in team sports. Journal of Teaching in Physical Education, 16, 500516.

Hernandez, J. (1988). Baloncesto iniciacion y entrenamiento [Basketball initiation and training]. Barcelona, ES: Editorial Paidotribo.

Javier, O. (1992). 1250 ejercicios y juegos en baloncesto [1250 basketball drills and playes]. Barcelona, ES: Editorial Paidotribo.

Janković, V. (1988). Latentna struktura tehničko - taktičkih elemenata u odbojkaškoj igri [Latent structure of the technical - tactical elements in volleyball game]. Kineziologija, 20(1), 57-62.

Jeličić, M., Trninić, M., \& Jelaska, I. (2010). Latent structure of situational efficiency of elite junior basketball players. Sport Science, 3(1), 65-70.

Jukić, I. (1998). Praćenje motoričko-funkcionalne pripremljenosti u jednogodišnjem ciklusu treninga vrhunskih košarkašica [Monitoring motorfunctional preparation in the one-cycle training of top female basketball players]. Unpublished master thesis, University of Zagreb, Faculty of Physical Culture.

Milanović, D., Jukić, I., \& Bračić, M. (2001). Utjecaj varijabli ubacivanja lopte u koš na rezultate košarkaških utakmica Prvenstva Europe u Barceloni 1997. godine [Influence of variables basketball shooting on the game results of the European Championships in Barcelona 1997]. In D. Milanović (Ed.) Zbornik radova Kineziologija za 21. stoljeće (pp. 286-289). Opatija, HR: Fakultet za fizičku kulturu.

Milanović, D., Jukić, I., \& Dizdar, D. (1996). Dijagnostika funkcionalnih i motoričkih sposobnosti kao kriterij za selekciju košarkaša Diagnosis of functional and motor abilities as a criterion for the selection in basketball]. Kineziologija, 28(2), 42-45.

Nakić, J. (2004). Razlike u standardnim i izvedenim parametrima situacijske učinkovitosti izmedu muških $i$ ženskih košarkaških ekipa na seniorskim košarkaškim europskim prvenstvima 2003. godine [Differences in standard and derived parameters situational performance between male and female

Primljeno: 6. septembra 2012

Izmjene primljene: 6. decembar 2012

Odobreno: 6. decembar 2012 basketball teams in the senior European basketball championships 2003]. Unpublished master thesis, University of Zagreb, Faculty of Kinesiology.

Sindik, J. (2009). Povezanost konativnih obilježja vrhunskih košarkaša i situacijske ucinkovitosti u košarci [Correlation conative characteristics and situational performance of top level basketball players]. Unpublished doctoral dissertation, University of Zagreb, Faculty of Kinesiology.

Swalgin, K. (1994). The basketball evaluating system. A scientific approach to player evaluation. In J. Krausse (Ed.), Coaching basketball (pp. 40-43). Indianapolis, IN: Master Press.

Swalgin, K. (1998). Sustav ocjenjivanja u košarci [Evaluation system in basketball]. Kineziologija, 30(1), 30-36.

Šeparović, V., \& Nuhanović, A. (2008). Latent structure of standard indicators of situational effectiveness in basketball in Bosnian league 6. Sport Scientific and Practical Aspects, 5(1/2), 13-18.

Thompson, J. (1994). Inside players. In J. Krause (Ed.), Coaching basketball (pp. 40-43). Indianapolis, IN: Master Press..

Trninić, S., \& Dizdar, D. (2000). System of the performance evaluation criteria weighted per positions in the basketball game. Collegium Antropologicum, 24(1), 217-234.

Trninić, S., Perica, A., \& Dizdar, D. (1999). Set of criteria for the actual quality evaluation of the elite basketball players. Collegium Antropologicum, 23(2), 707-721.

Trninić S., Perica, A., \& Dizdar, D. (2001). Criteria for the situation related efficiency evaluation of the elite basketball players. In D. Milanović (Ed.), Kineziologija za 21. stoljeće (pp. 236-239. Opatija, HR: Fakultet za fizičku kulturu.

Trninić, S., Viskić-Štalec, N., Štalec, J., Dizdar D., \& Birkić, Ž. (1995). Latentna struktura standardnih pokazatelja situacijske efikasnosti u košarkaškoj igri [Latent structure of the standard indicators of situational efficiency in basketball game]. Kineziologija, 27(1), 27-37.

Wissel, H. (1994). Basketball: Step to success. Champaign, IL: Human Kinetics.

Korespondencija: Dr Joško Sindik Institut za antroplologiju Gajeva 22 10000 Zagreb Hrvatska

Telefon: 0038515535122 E-mail: josko.sindik@inantro.hr 